\title{
Article \\ Use of Potabilized Water Sludge in the Production of Low-Energy Blended Calcium Sulfoaluminate Cements
}

\author{
Antonio Telesca (D), Neluta Ibris and Milena Marroccoli *(D) \\ Scuola di Ingegneria, Università degli Studi della Basilicata, Viale dell'Ateneo Lucano 10, 85100 Potenza, Italy; \\ antonio.telesca@unibas.it (A.T.); neluta.ibris@unibas.it (N.I.) \\ * Correspondence: milena.marroccoli@unibas.it
}

Citation: Telesca, A.; Ibris, N.; Marroccoli, M. Use of Potabilized Water Sludge in the Production of Low-Energy Blended Calcium Sulfoaluminate Cements. Appl. Sci. 2021, 11, 1679. https://doi.org/ 10.3390/app11041679

Academic Editor: Fortunato Crea

Received: 15 January 2021

Accepted: 9 February 2021

Published: 13 February 2021

Publisher's Note: MDPI stays neutral with regard to jurisdictional claims in published maps and institutional affiliations.

Copyright: (c) 2021 by the authors. Licensee MDPI, Basel, Switzerland. This article is an open access article distributed under the terms and conditions of the Creative Commons Attribution (CC BY) license (https:// creativecommons.org/licenses/by/ $4.0 /)$.

\begin{abstract}
Ordinary Portland cement (OPC) manufacture determines about $8 \%$ of the global anthropogenic $\mathrm{CO}_{2}$ emissions. This has led to both the cement producers and the scientific community to develop new cementitious materials with a reduced carbon footprint. Calcium sulfoaluminate (CSA) cements are special hydraulic binders from non-Portland clinkers; they represent an important alternative to OPC due to their peculiar composition and significantly lower impact on the environment. CSA cements contain less limestone and require lower synthesis temperatures, which means a reduced kiln thermal energy demand and lower $\mathrm{CO}_{2}$ emissions. CSA cements can also be mixed with supplementary cementitious materials (SCMs) which further reduce the carbon footprint. This article was aimed at evaluating the possibility of using different amounts (20 and 35\% by mass) of water potabilization sludges (WPSs) as SCM in CSA-blended cements. WPSs were treated thermally (TT) at $700^{\circ}$ in order to obtain an industrial pozzolanic material. The hydration properties and the technical behavior of two different CSA-blended cements were investigated using differential thermal-thermogravimetric and X-ray diffraction analyses, mercury intrusion porosimetry, shrinkage/expansion and compressive strength measurements. The results showed that CSA binders containing $20 \%$ by mass of TTWPSs exhibited technological properties similar to those relating to plain CSA cement and were characterized by more pronounced eco-friendly features.
\end{abstract}

Keywords: low- $\mathrm{CO}_{2}$ binders; calcium sulfoaluminate cements; supplementary cementitious materials; hydration; expansion; mechanical strength

\section{Introduction}

The cement manufacturing industry is one of the largest consumers of fuel and raw materials, and one of the main producers of $\mathrm{CO}_{2}$ emissions [1]. In 2019, worldwide production of Portland cement was estimated at 4.10 billion tonnes, producing $8 \%$ of global anthropogenic carbon dioxide emissions [2]. The cement industry needs to reduce its carbon footprint to 1.55 billion metric tonnes per year by 2050 [3]; in order to do this, the cement producers and the research community have been striving to develop new environmentally friendly binders (low- $\mathrm{CO}_{2}$ cements [4-9]).

Three different approaches have been proposed for the manufacture of low- $\mathrm{CO}_{2}$ cements: (1) the utilization of non-carbonated sources of $\mathrm{CaO}$ instead of limestone as a constituent of Portland clinker (PC)-generating raw mix [10,11]; (2) the increased production of blended cements, obtained by mixing ordinary Portland cement (OPC) with high amounts of supplementary cementitious materials (SCMs) [12-17]; (3) the larger use of special cements (SCs), namely, hydraulic binders obtained from non-PCs [18-25].

Calcium sulfoaluminate (CSA) cements have prompted the interest of the international cement research community for both their valuable technical properties and environmentally friendly features mainly associated with their manufacturing process [26,27]. CSA cements contain ye'elimite $\left(3 \mathrm{CaO} \cdot 3 \mathrm{Al}_{2} \mathrm{O}_{3} \cdot \mathrm{CaSO}_{4}\right)$ as the main component, and, depending on the synthesis temperature and the type and proportioning of raw materials (usually 
limestone, bauxite and natural gypsum), calcium sulfates (e.g., $\mathrm{CaSO}_{4}, \mathrm{CaSO}_{4} \cdot 2 \mathrm{H}_{2} \mathrm{O}$ ), belite $\left(2 \mathrm{CaO} \cdot \mathrm{SiO}_{2}\right)$, brownmillerite $\left(4 \mathrm{CaO} \cdot \mathrm{Al}_{2} \mathrm{O}_{3} \cdot \mathrm{Fe}_{2} \mathrm{O}_{3}\right)$, ternesite $\left(4 \mathrm{CaO} \cdot \mathrm{SiO}_{2} \cdot \mathrm{CaSO}_{4}\right)$ and various calcium aluminates. The most significant technical properties of CSA cements (e.g., shrinkage compensation/self-stressing behavior, good dimensional stability, high impermeability, rapid hardening) are mainly regulated by the formation of ettringite $\left(3 \mathrm{CaO} \cdot \mathrm{Al}_{2} \mathrm{O}_{3} \cdot 3 \mathrm{CaSO}_{4} \cdot 32 \mathrm{H}_{2} \mathrm{O}\right)$ from the hydration of calcium sulfates (belonging and/or added to CSA clinker) and $3 \mathrm{CaO} \cdot 3 \mathrm{Al}_{2} \mathrm{O}_{3} \cdot \mathrm{CaSO}_{4}$ [28-32] with or without $\mathrm{CaO}$, according to the following reactions:

$$
\begin{gathered}
3 \mathrm{CaO} \cdot 3 \mathrm{Al}_{2} \mathrm{O}_{3} \cdot \mathrm{CaSO}_{4}+2 \mathrm{CaSO}_{4}+38 \mathrm{H}_{2} \mathrm{O} \Longrightarrow 3 \mathrm{CaO} \cdot \mathrm{Al}_{2} \mathrm{O}_{3} \cdot 3 \mathrm{CaSO}_{4} \cdot 32 \mathrm{H}_{2} \mathrm{O}+2 \mathrm{Al}_{2} \mathrm{O}_{3} \cdot 6 \mathrm{H}_{2} \mathrm{O} \\
3 \mathrm{CaO} \cdot 3 \mathrm{Al}_{2} \mathrm{O}_{3} \cdot \mathrm{CaSO}_{4}+8 \mathrm{CaSO}_{4}+6 \mathrm{CaO}+96 \mathrm{H}_{2} \mathrm{O} \Longrightarrow 3\left(3 \mathrm{CaO} \cdot \mathrm{Al}_{2} \mathrm{O}_{3} \cdot 3 \mathrm{CaSO}_{4} \cdot 32 \mathrm{H}_{2} \mathrm{O}\right)
\end{gathered}
$$

Ettringite generated in the presence of $\mathrm{CaO}$ (Reaction (2)) expands and this behavior can be exploited by special binders such as shrinkage-resistant and self-stressing cements. Ettringite produced in Reaction (1) is not expansive and has a high mechanical strength at early ages.

Furthermore, various other hydration products may occur, such as calcium silicate hydrate (C-S-H) and strätlingite (STR), respectively, according to Reactions (3) and (4):

$$
\begin{gathered}
2 \mathrm{CaO} \cdot \mathrm{SiO}_{2}+(1.5+\mathrm{n}) \mathrm{H}_{2} \mathrm{O} \Longrightarrow(1.5+\mathrm{m}) \mathrm{CaO} \cdot \mathrm{SiO}_{2} \cdot(1+\mathrm{m}+\mathrm{n}) \mathrm{H}_{2} \mathrm{O}+(0.5-\mathrm{m}) \mathrm{Ca}(\mathrm{OH})_{2} \\
2 \mathrm{CaO} \cdot \mathrm{SiO}_{2}+\mathrm{Al}_{2} \mathrm{O}_{3} \cdot 3 \mathrm{H}_{2} \mathrm{O}+5 \mathrm{H}_{2} \mathrm{O} \Longrightarrow 2 \mathrm{CaO} \cdot \mathrm{Al}_{2} \mathrm{O}_{3} \cdot \mathrm{SiO}_{2} \cdot 8 \mathrm{H}_{2} \mathrm{O}
\end{gathered}
$$

Compared to the OPC manufacturing process, CSA cements exhibit the following environmentally friendly features: (I) reduced limestone requirement (usually $<35 \%$ ), and therefore less kiln thermal input and $\mathrm{CO}_{2}$ generation; (II) lower synthesis temperatures (about $150{ }^{\circ} \mathrm{C}-200{ }^{\circ} \mathrm{C}$ ) and more friable clinkers (lower grinding energy required); (III) larger clinker dilution with additions of sulfate sources; (IV) greater use of industrial wastes, especially as kiln feed components [33-40]. To further decrease $\mathrm{CO}_{2}$ emissions, CSA cements can be blended with various SCMs and/or mineral additions [41-60].

Water potabilization sludges (WPSs) are clayish residues produced during the treatment of water for human consumption in conventional water treatment plants (WTPs) [61]. Water potabilization treatments are mainly based on coagulation (generally using an alumina-based coagulant) and flocculation processes; they generate high quantities of sludges which represent about $1-5 \%$ of the total untreated water. Huge amounts of WPSs are produced worldwide ( 10,000 tonnes/day); consequently, suitable alternatives to landfill need to be explored. Up to now, WPSs have been suggested in the production of bricks, ceramics, lightweight aggregates and for the manufacturing process of cement as an alternative raw material [62].

This paper investigated the possibility of using thermally treated WPSs (TTWPSs) as SCMs in CSA-blended cements; thanks to the thermal treatment, crystalline clay phases were transformed in a predominantly amorphous state (dehydroxylation process). The optimal treatment temperature, namely the one that allows the total sample dehydroxylation [63], is usually in the range $600^{\circ} \mathrm{C}-900{ }^{\circ} \mathrm{C}$ for clay-based materials. Two CSA-blended cements, based on TTWPSs, were submitted to physical-mechanical and hydration tests at curing times ranging from $4 \mathrm{~h}$ to 56 days. A neat CSA cement was used as a reference term. The influence of TTWPSs on the hydration properties and the physical and technical behavior of blended cements was investigated by means of differential thermalthermogravimetric (DT-TG ) and quantitative X-ray diffraction (QXRD) analyses, mercury intrusion porosimetry (MIP), shrinkage/expansion and compressive strength measurements.

\section{Materials and Methods}

\subsection{Materials}

An industrial CSA cement was used in this investigation; it was kindly supplied by an Italian cement manufacturer. The WPSs were obtained from the water treatment plant of the "Camastra" artificial reservoir, which is located in Basilicata, Italy. The WPS sample 
was first dried in an electric oven at $105^{\circ} \mathrm{C}$ until a constant mass value was reached; then it was finely pulverized in a Fritsch Pulverisette 6 (FP6) laboratory planetary mill and passed through a $90 \mu \mathrm{m}$ sieve. The WPS sample was finally heated for two hours in an electric oven at $700{ }^{\circ} \mathrm{C}$, namely, the optimal treatment temperature for its total dehydroxylation [64]; the TTWPSs were finely pestled in order to pass through the $90 \mu \mathrm{m}$ sieve again.

\subsection{Test Methods and Characterization Techniques}

The chemical composition of the CSA cement, the WPSs and the TTWPSs was evaluated using a X-ray fluorescence apparatus (BRUKER Explorer S4, Bruker Italy, Milan, Italy); a BRUKER D2 PHASER diffractometer (LynxEye detector, $\mathrm{Cu} \mathrm{K} \alpha$ radiation and $0.02^{\circ} 2 \theta \mathrm{s}^{-1}$ scanning rate) was used to identify the main CSA cement phases (Table 1 ) and the principal mineralogical compounds of hydrated pastes, quantitatively estimated using the Rietveld refinement method. The specific surface and the particle size distribution of both CSA cement and TTWPSs were determined using the Blaine apparatus and a laser particle analyzer (Malvern Mastersizer 2000, Malvern-Panalytical Italy, Milan, ITaly), respectively.

Table 1. Chemical and mineralogical (only for CSA cement) composition of the used binder components, wt \%.

\begin{tabular}{|c|c|c|c|c|c|c|}
\hline & \multicolumn{3}{|c|}{ Chemical Composition } & \multicolumn{3}{|c|}{ Mineralogical Phase Composition } \\
\hline & CSA Cement & WPSs & TTWPSs & CSA Cement & ICDD Ref. Number & \\
\hline $\mathrm{CaO}$ & 44.58 & 4.95 & 6.26 & Ye'elimite & $30-0256$ & 43.0 \\
\hline $\mathrm{SiO}_{2}$ & 8.95 & 37.71 & 47.66 & $\beta$-belite & $33-0302$ & 21.7 \\
\hline $\mathrm{Al}_{2} \mathrm{O}_{3}$ & 22.42 & 27.52 & 34.78 & Celite & $38-1429$ & 3.8 \\
\hline $\mathrm{Fe}_{2} \mathrm{O}_{3}$ & 1.86 & 2.37 & 3.00 & Anhydrite & $37-1496$ & 19.1 \\
\hline $\mathrm{TiO}_{2}$ & 1.10 & 0.35 & 0.44 & Calcite & $05-0586$ & 1.1 \\
\hline $\mathrm{K}_{2} \mathrm{O}$ & 0.30 & 1.01 & 1.28 & Brownmillerite & $30-0256$ & 4.5 \\
\hline $\mathrm{MnO}$ & 0.08 & 0.33 & 0.42 & Gehlenite & 73-2041 & 1.6 \\
\hline $\mathrm{Na}_{2} \mathrm{O}$ & 0.08 & 0.35 & 0.44 & Others & - & 5.2 \\
\hline $\mathrm{MgO}$ & 0.94 & 1.18 & 1.49 & & & \\
\hline $\mathrm{Cl}$ & 0.07 & 0.01 & 0.01 & & & \\
\hline $\mathrm{SO}_{3}$ & 16.85 & 0.53 & 0.67 & & & \\
\hline $\mathrm{P}_{2} \mathrm{O}_{5}$ & 0.05 & 1.18 & 1.49 & & & \\
\hline 1.o.i ${ }^{*}$ & 2.16 & 22.12 & 1.56 & & & \\
\hline Total & 99.44 & 99.61 & 99.50 & Total & & 100.0 \\
\hline
\end{tabular}

Three CSA-based binders were investigated: a neat CSA cement (CSAR) and two blended CSA cements, both containing TTWPSs as a partial substitute for CSA cement in concentrations equal to $20 \%$ and $35 \%$ by mass (CSA20 and CSA35).

To obtain expansion/shrinkage (e/s) measurements, eighteen paste samples $(15 \times 15$ $\times 78 \mathrm{~mm}$ ) were prepared using $150 \mathrm{~g}$ of binder (b) per system and $97.5 \mathrm{~g}$ of distilled water $(\mathrm{w})($ water/binder mass ratio, $\mathrm{w} / \mathrm{b},=0.65)$; the pastes were mechanically stirred for $120 \mathrm{~s}$, placed in stainless-steel molds and covered with plastic foils. The samples were first cured in the air at $20^{\circ} \mathrm{C}$ for $8 \mathrm{~h}$ and then demolded. Three samples per system were aged at $20^{\circ} \mathrm{C}$ under tap water; the other three samples were stored at the same temperature in a climatic chamber at 50\% relative humidity (R.H.) The length changes were determined as average values of three measurements taken with a length comparator; measurements were taken daily until 56 days of curing.

The compressive mechanical strength measurements were carried out on mortars prepared according to EN 196-1 and cured for periods of up to 56 days. 
For DT-TG, QXRD and MIP analyses, paste samples were prepared according to the same procedure employed for the e/s measurements. The hydration of the pastes was examined from $4 \mathrm{~h}$ to 56 days. For each hydration time, $20 \mathrm{~g}$ of binder was mixed with distilled water using a w/b mass ratio of 0.65 . The pastes were cast into $15 \mathrm{~mm}$ high and $30 \mathrm{~mm}$ diameter plastic cylindrical molds, sealed to minimize $\mathrm{CO}_{2}$ ingress and cured in a thermostatic bath (at $20{ }^{\circ} \mathrm{C}$ and $95 \%$ R.H.). At the end of the fixed aging period, each sample was broken in half: one part was submitted to MIP, the other gently pulverized for DT-TG and QXRD analyses. Both hardened fragments and fine powder were handled with acetone (to stop hydration) and diethyl ether (to remove water); the samples were finally stored in a desiccator over silica gel-soda lime to ensure protection against $\mathrm{H}_{2} \mathrm{O}$ and $\mathrm{CO}_{2}$.

DT-TG analysis was conducted on $100 \mathrm{mg}$ samples (put in $150 \mu \mathrm{L}$ alumina crucibles) using a Netzsch Tasc 414/3 simultaneous thermal analyzer, operating in air in the temperature range of $20^{\circ} \mathrm{C}-1000{ }^{\circ} \mathrm{C}$ and with a heating rate of $10^{\circ} \mathrm{C} / \mathrm{min}$. TG analysis was also employed for the determination of the chemically bound water (calculated from the weight loss between $30^{\circ} \mathrm{C}$ and $500{ }^{\circ} \mathrm{C}$ ). The porosity measurements were performed using a Thermo Finnigan Pascal 240 Series porosimeter (maximum pressure, $200 \mathrm{MPa}$ ) equipped with a low-pressure unit (140 Series) able to generate a high vacuum level (10 Pa) and operating from 100 to $400 \mathrm{kPa}$.

\section{Results and Discussion}

Table 1 shows the chemical composition of CSA cement, WPSs and TTWPSs; it also reports the mineralogical composition of CSA cement determined using the Rietveld method whose results were normalized to $100 \%$ of the accounted crystalline phases.

From the chemical analysis it can be argued that CSA cement was mainly composed of $\mathrm{CaO}, \mathrm{Al}_{2} \mathrm{O}_{3}, \mathrm{SO}_{3}$ and $\mathrm{SiO}_{2}$, in that order; the Rietveld analysis indicates that the main crystalline components of the CSA cement were in the following order: ye'elimite (43.0 mass $\%$ ), belite, brownmillerite, celite $\left(3 \mathrm{CaO} \cdot \mathrm{Al}_{2} \mathrm{O}_{3}\right)$ and gehlenite $\left(2 \mathrm{CaO} \cdot \mathrm{Al}_{2} \mathrm{O}_{3} \cdot \mathrm{SiO}_{2}\right)$; furthermore, $\mathrm{CaSO}_{4}$ was also present, mainly from the addition of natural anhydrite.

The chemical composition of TTWPS reveals that $\mathrm{SiO}_{2}\left(47.7\right.$ mass \%) and $\mathrm{Al}_{2} \mathrm{O}_{3}$ (34.8 mass\%) were the main oxides; $\mathrm{CaO}$ (6.3 mass\%) and $\mathrm{Fe}_{2} \mathrm{O}_{3}$ (3.0 mass\%) were present as secondary components, while fairly low amounts of $\mathrm{SO}_{3}, \mathrm{MgO}, \mathrm{K}_{2} \mathrm{O}$ and $\mathrm{Na}_{2} \mathrm{O}$ were also found.

The specific surfaces for both CSA and TTWPSs (measured according to EN 196-6) were equal to $4500 \pm 50$ and $4300 \pm 50 \mathrm{~cm}^{2} / \mathrm{g}$, respectively; $D_{10}$ and $D_{90}$ values for the two materials were very similar to each other, $2.5 \mu \mathrm{m}$ and $3.1 \mu \mathrm{m}$ and $67.3 \mu \mathrm{m}$ and $72.7 \mu \mathrm{m}$ for CSA cement and TTWPSs, respectively.

Figure 1 shows the e/s curves (in terms of length changes) for CSAR, CSA20 and CSA35. They indicate that the three systems differed very little from each other, both when submerged under water and cured in air.

The maximum expansion values were reached after about 15-20 days of curing and were in a very narrow range $(0.02-0.06 \%)$. When air cured, TTWPS-based pastes showed a rapid shrinkage during the first five days of hydration; for both systems, the minimum shrinkage value $(-0.18 \%$ for CSA20 and $-0.20 \%$ for CSA35) was reached after about 20 days of curing; however, a less rapid shrinkage was exhibited by the CSAR system which approached a steady value (almost $-0.18 \%$ ) only after about 20 days of hydration.

Figure 2 reports the mechanical compressive strength values for CSA-based mortars at different curing times ( 4 and $16 \mathrm{~h}, 1,2,7,28$ and 56 days); the CSAR compressive strength values were higher than those of the two blended cements at the shortest curing period ( $22 \%$ and $54 \%$ higher than those of CSA20 and CSA35 systems, respectively); with an increase in curing time, the mechanical compressive strength gap reduced for the three systems. 


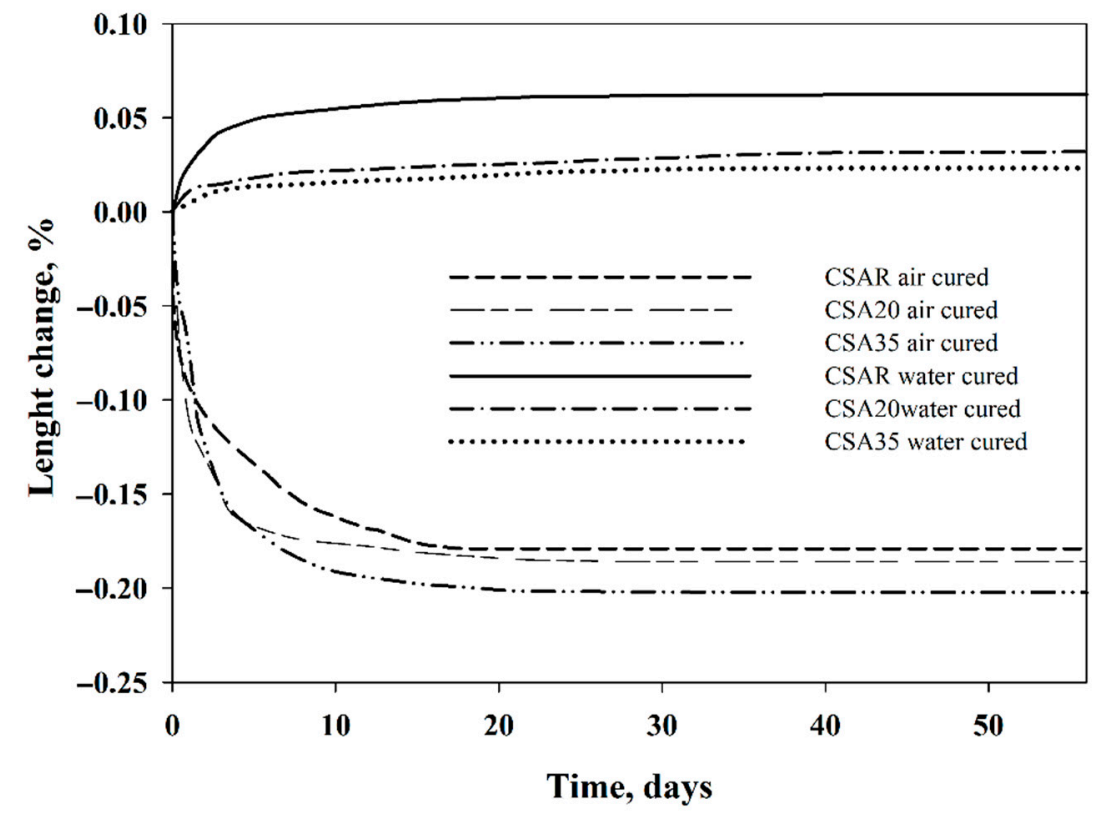

Figure 1. Dimensional stability curves for CSAR, CSA20 and CSA35 pastes (air and water cured) at a $\mathrm{w} / \mathrm{b}$ of 0.65 .

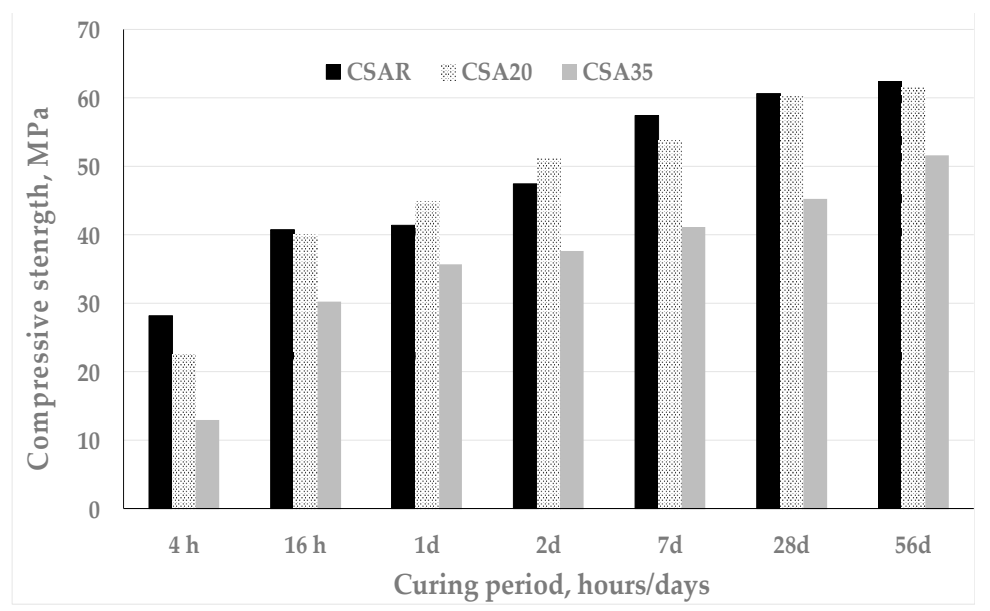

Figure 2. Compressive strength measurements for CSAR, CSA20 and CSA35 mortars cured within the period $4 \mathrm{~h}-56$ days.

Finally, after 28 and 56 days of curing, the CSA20-based mortars exhibited almost identical compressive mechanical strength values as the reference mortar; however, the compressive mechanical strength values of the CSA35-based mortars were about $25 \%$ and $18 \%$ lower than those of the CSAR at 28 and 56 days of curing.

Figure 3 displays the DT (left)-TG (right) results for CSAR, CSA20 and CSA35 aged for periods in the range $4 \mathrm{~h}-56$ days.

According to data from scientific literature [65], the following phases, in the order of increasing temperature of the related endothermal effect, were attributed to calcium silicate hydrates (C-S-H), ettringite (E), aluminum hydroxide $\left(\mathrm{AH}_{3}\right)$ and calcium carbonate (CC); these phases were observed at $117{ }^{\circ} \mathrm{C} \pm 3{ }^{\circ} \mathrm{C}, 159^{\circ} \mathrm{C} \pm 9{ }^{\circ} \mathrm{C}, 281^{\circ} \mathrm{C} \pm 5^{\circ} \mathrm{C}$ and $725^{\circ} \mathrm{C} \pm$ $7{ }^{\circ} \mathrm{C}$. 

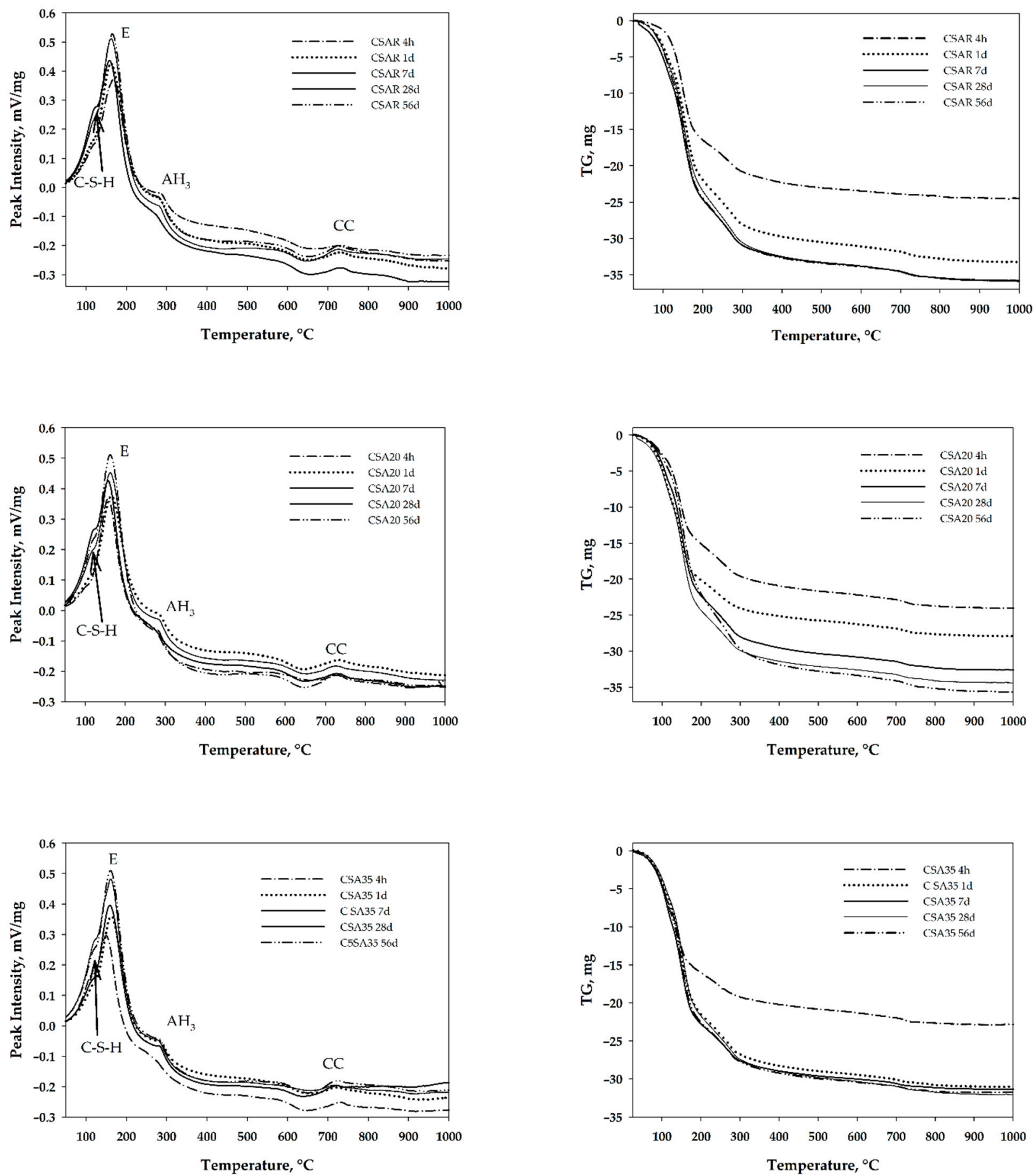

Figure 3. DT (left)-TG (right) results for CSAR (top), CSA20 (middle) and CSA35 (bottom) pastes hydrated (w/b = 0.65) for $4 \mathrm{~h}, 1,7,28$ and 56 days. Legend: $\mathrm{C}-\mathrm{S}-\mathrm{H}=$ calcium silicate hydrates; $\mathrm{E}=$ ettringite; $\mathrm{AH}_{3}=$ aluminum hydroxide; $\mathrm{CC}=$ calcium carbonate.

Negligible exo-/endo-thermal effects were found above $600{ }^{\circ} \mathrm{C}$; in fact, weight losses in the range $600{ }^{\circ} \mathrm{C}-1000{ }^{\circ} \mathrm{C}$ were always lower than $2.3 \%$ which means, according to [57], that carbonation process was minimal. On the whole, the DT-TG results indicate that the hydration behavior of the investigated systems was mainly regulated by the reaction of ye'elimite with calcium sulfate alone (especially at early ages) and also by the formation of C-S-H. The latter formed according to the Reaction (3) and thanks to the pozzolanic 
reaction of reactive $\mathrm{SiO}_{2}$ (belonging to TTWPSs) with calcium hydroxide (generated as secondary product in (3)).

The hydration rates of the three CSA-based systems were also evaluated using the amount of chemically bound water (Figure 4) calculated from the mass loss values from TG analyses (Figure 3) normalized to $100 \mathrm{~g}$ dry binder.

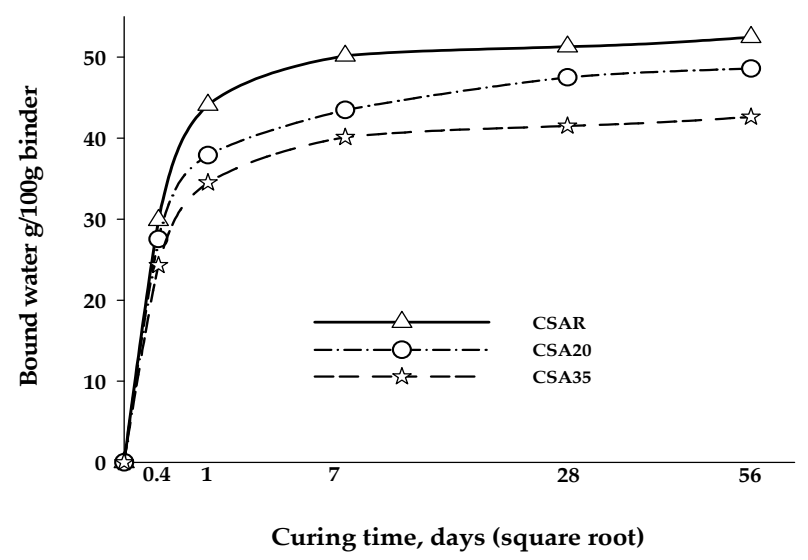

Figure 4. Bound water as determined by TG up to 56 days of hydration $(w / b=0.65$ and normalized to $100 \mathrm{~g}$ dry binder) for CSAR, CSA20 and CSA35 pastes vs. curing time.

Figure 4 clearly shows that the three binders followed a similar evolution within the first $24 \mathrm{~h}$; during this period the rate of hydration was very high due to the rapid formation of ettringite, followed by the slower formation of hydration products. From 7 days of curing, the curve of the CSAR exhibits an almost constant value, while the curves of the blended cements show a slight linear increase owing to the pozzolanic reaction of TTWPSs.

The hydration process was also examined using QXRD analysis which detected the reactants consumption, the presence of inert phases and the development of new products. Figure 5 displays the patterns of the binders hydrated at 4 h, 28 and 56 days.
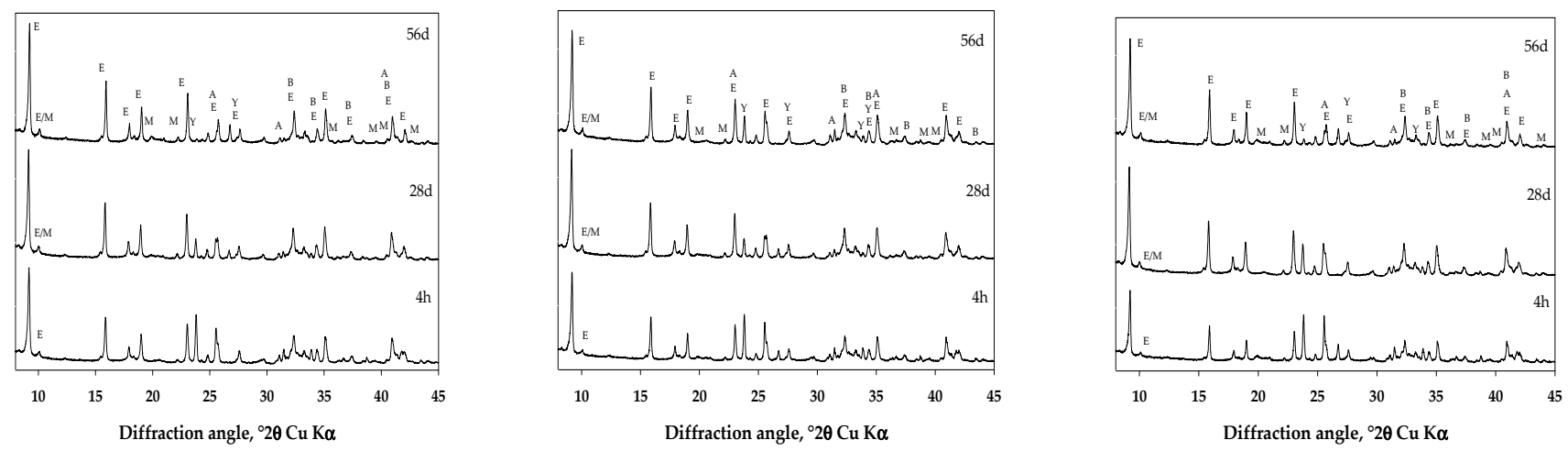

Figure 5. XRD patterns for CSAR (left), CSA20 (middle) and CSA35 (right) pastes hydrated ( $\mathrm{w} / \mathrm{b}=0.65)$ for $4 \mathrm{~h}$, 28 and 56 days. Legend: $\mathrm{A}=\mathrm{CaSO}_{4} ; \mathrm{B}=2 \mathrm{CaO} \cdot \mathrm{SiO}_{2} ; \mathrm{E}=3 \mathrm{CaO} \cdot \mathrm{Al}_{2} \mathrm{O}_{3} \cdot 3 \mathrm{CaSO}_{4} \cdot 32 \mathrm{H}_{2} \mathrm{O} ; \mathrm{Y}=3 \mathrm{CaO} \cdot 3 \mathrm{Al}_{2} \mathrm{O}_{3} \cdot \mathrm{CaSO}_{4}$; $\mathrm{M}=3 \mathrm{CaO} \cdot \mathrm{Al}_{2} \mathrm{O}_{3} \cdot \mathrm{CaSO}_{4} \cdot 12 \mathrm{H}_{2} \mathrm{O}$.

The evolution of the hydration process, in terms of ettringite, ye'elimite and belite concentration, at different hydration times, is reported in Figure 6. The concentration values were determined according to the Rietveld method and normalized to $100 \%$ of the accounted crystalline phases. From and overall examination of both Figures 5 and 6, it can be drawn that XRD results fit well with the indications from DT-TG analyses. 

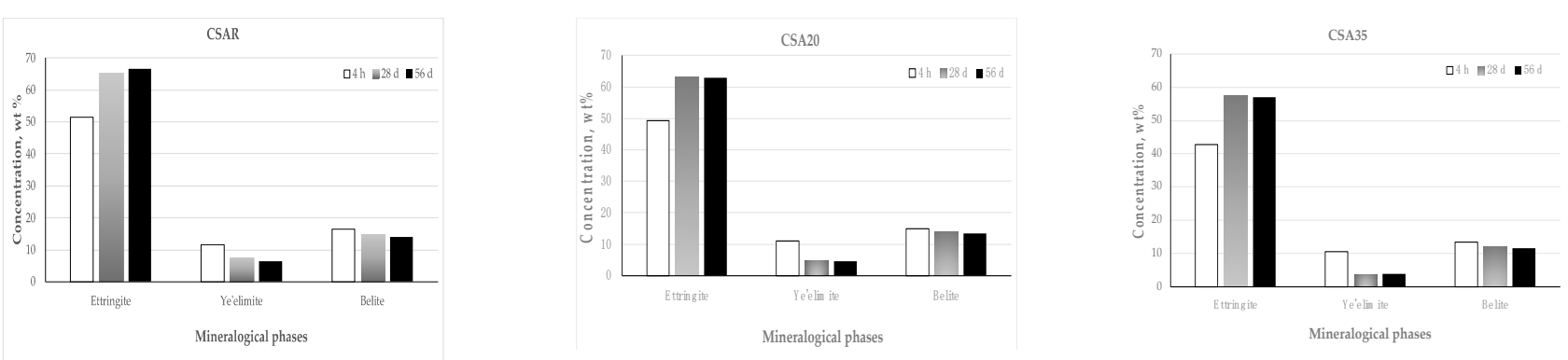

Figure 6. Ettringite, ye'elimite and belite concentrations as determined by the Rietveld method at 4 h, 28 and 56 days of curing.

In fact, as far as the hydration products were concerned, $3 \mathrm{CaO} \cdot 3 \mathrm{Al}_{2} \mathrm{O}_{3} \cdot \mathrm{CaSO}_{4}$ and $\mathrm{CaSO}_{4}$ quickly reacted, and ettringite concentrations increased up to 56 days of curing. Weak signals relating to the presence of monosulfate appeared from 28 days of curing in the three investigated systems. This phase was not identified using DT-TG apparatus as its endothermic peak was always overlapped by that of ettringite. The absence of $\mathrm{AH}_{3}$ in the crystalline phases detected using XRD analysis is related to its amorphous nature [33].

Figure 7 reports the porosimetric curves for the pastes of the three investigated binders; the left and the right areas in the figure show the cumulative and derivative plots for the intruded $\mathrm{Hg}$ volume of CSA-based systems vs. pore radius at various curing times (4 h, 7 and 56 days). It clearly shows that with an increase in curing time both total porosity and threshold pore width reduced. For the CSAR (Figure 7, top), all the differential curves were characterized by a bimodal pores size distribution centered on the threshold width of pore necks connecting a continuous system. Between $4 \mathrm{~h}$ and 56 days of curing, the threshold pore radii, respectively, reduced from about $270 \mathrm{~nm}$ and $11 \mathrm{~nm}$ to $110 \mathrm{~nm}$ and $10 \mathrm{~nm}$; in the same period the total cumulative volume decreased from about $258 \mathrm{~mm}^{3} / \mathrm{g}$ to $149 \mathrm{~mm}^{3} / \mathrm{g}$.

Compared to the reference system, CSA20-based paste (Figure 7, middle) displayed a trimodal pore size distribution for all the investigated curing times; furthermore, at the shortest and longest curing times, the highest pore widths ranged from $196 \mathrm{~nm}$ to $66 \mathrm{~nm}$, while the lowest was below to the detectable apparatus limit $(3.6 \mathrm{~nm})$; likewise, its cumulative pore volume lowered of about $40 \%$ (passing from $254 \mathrm{~mm}^{3} / \mathrm{g}$ to $149 \mathrm{~mm}^{3} / \mathrm{g}$ ) from $4 \mathrm{~h}$ to 7 days; after 56 days of curing it further decreased to $131 \mathrm{~mm}^{3} / \mathrm{g}$. For the CSA35 system (Figure 7, bottom), the cumulative pore volume reduced of about $45 \%$ (from $289 \mathrm{~mm}^{3} / \mathrm{g}$ to $160 \mathrm{~mm}^{3} / \mathrm{g}$ ) from $4 \mathrm{~h}$ to 56 days of curing; in addition, similarly to the CSA20 system, a trimodal pore size distribution at all the investigated curing times was exhibited.

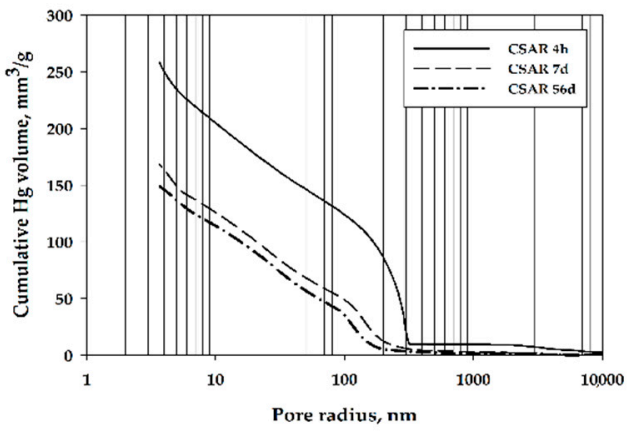

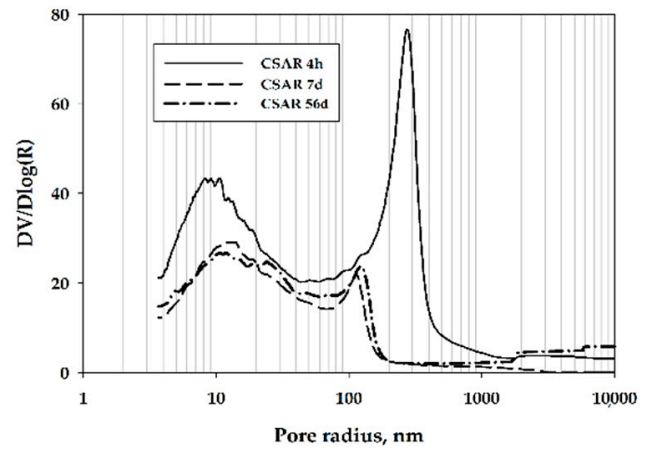

Figure 7. Cont. 

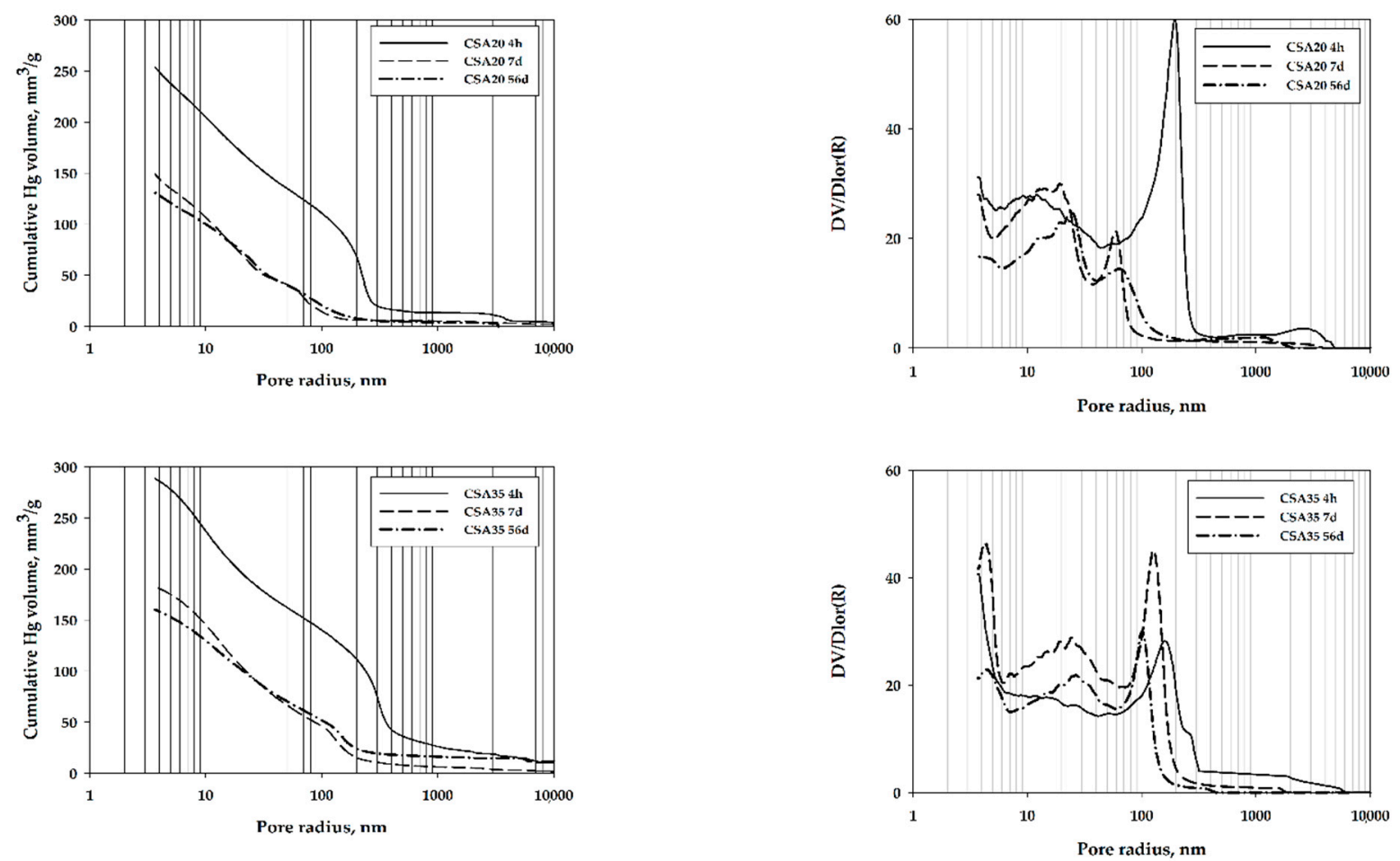

Figure 7. Cumulative (left) and derivative (right) $\mathrm{Hg}$ volume vs. pore radius for CSAR (top), CSA20 (middle) and CSA35 (bottom) pastes hydrated $(\mathrm{w} / \mathrm{b}=0.65)$ for $4 \mathrm{~h}, 7$ and 56 days.

The total porosity percentage (TP) of the investigated systems vs. curing time is illustrated in Figure 8; the related curves clearly show a similar trend for all binders whose $\mathrm{TP}$ values decrease with an increase in hydration time.

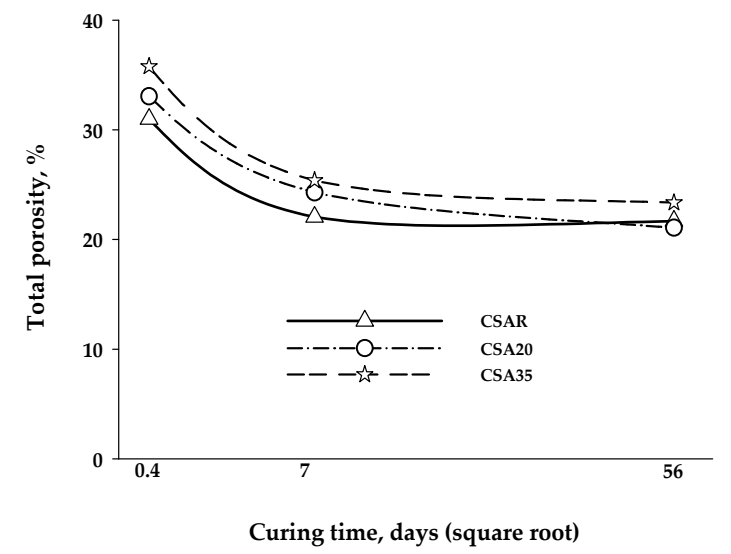

Figure 8. Total porosity for CSAR, CSA20 and CSA35 pastes hydrated $(w / b=0.65)$ for $4 \mathrm{~h}, 7$ and 56 days.

In particular, at $4 \mathrm{~h}$ and 7 days of hydration, TP was lowest for the plain CSA cement and highest for the blend with $35 \%$ by mass of TTWPSs; in this period, the reduction rate of porosity was higher than that exhibited from 7 days to 56 days of curing for the three systems. Finally, at 56 days of curing, the total porosity of CSAR $(21.7 \%)$ was slightly higher than that of CSA20 (21.1\%) and lower than that exhibited by CSA35 (23.4\%). 


\section{Environmental Implications of the Manufacture of CSA-Based Cements: Kiln Thermal Requirement and $\mathrm{CO}_{2}$ Emissions}

The kiln thermal requirement for the manufacture of OPC clinker is about $3450 \mathrm{MJ} / \mathrm{t}_{\text {clinker }}$, representing the average value of data reported in the scientific literature (3100-3800 MJ/t $\mathrm{t}_{\text {clinker }}$ ) [66-72]. $\mathrm{CO}_{2}$ specific emissions from the clinker burning process, generated by both limestone calcination $\left(0.54 \mathrm{t}_{\mathrm{CO} 2} / \mathrm{t}_{\mathrm{clinker}}\right)$ and fuel combustion, is estimated at about $0.86 \mathrm{t}_{\mathrm{CO} 2} / \mathrm{t}_{\text {clinker }}$; these data represent the average value calculated on the basis of several scientific papers $\left(0.83-0.89 \mathrm{t}_{\mathrm{CO} 2} / \mathrm{t}_{\text {clinker }}\right)[66,73,74]$. The energy consumption associated with CSA clinker manufacture accounts for about $2700 \mathrm{MJ} / \mathrm{t}_{\text {clinker }}$ [75]; furthermore, the amount of the emitted $\mathrm{CO}_{2}$ is around $25-35 \%$ lower than that generated in the production of OPC clinker $\left(0.86 \mathrm{t}_{\mathrm{CO} 2} / \mathrm{t}_{\text {clinker }}\right)[67,76-78]$. The energy saving and $\mathrm{CO}_{2}$ emission reduction become higher if we compare an OPC CEM I-type cement (composed by $95 \%$ clinker and $5 \%$ gypsum) with a CSA binder (constituted by $85 \%$ clinker and $15 \%$ gypsum); these reductions are even more significant if we blend CSA cements with SCMs, such as TTWPSs. In particular, if flash calcination is employed for the thermal treatment of WPSs, the energy required and the associated $\mathrm{CO}_{2}$ emissions are $2211 \mathrm{MJ} / \mathrm{t}_{\mathrm{WPSS}}$ and $0.20 \mathrm{t}_{\mathrm{CO} 2} / \mathrm{t}_{\mathrm{WPSS}}$, respectively $[79,80]$. The calculated values for both energy requirement and $\mathrm{CO}_{2}$ emissions for OPC and CSA-based binders are reported in Table 2.

Table 2. Calculated kiln thermal requirement $\left(\mathrm{MJ} / \mathrm{t}_{\text {binder }}\right)$ and total $\mathrm{CO}_{2}$ generated $\left(\mathrm{t}_{\mathrm{CO} 2} / \mathrm{t}_{\mathrm{binder}}\right)$.

\begin{tabular}{ccc}
\hline & Kiln Thermal Requirement & $\mathbf{C O}_{\mathbf{2}}$ Emissions \\
\hline OPC CEM I & 3280 & 0.82 \\
\hline CSAR & 2295 & 0.51 \\
\hline CSA20 & 2278 & 0.45 \\
\hline CSA35 & 2265 & 0.40 \\
\hline
\end{tabular}

The data of $\mathrm{CO}_{2}$ emissions for CSA-based binders can be normalized per compressive strength values $\left(\sigma_{28}\right)$ obtained at 28 days of curing $\left(\mathrm{NCO}_{2}\right)$, according to the following equation:

$$
\mathrm{NCO}_{2}=\frac{\mathrm{CO}_{2} \text { emissions }}{\sigma_{28}} \quad\left[\frac{\mathrm{t} \mathrm{tO}_{2}}{\mathrm{mPinder}}\right]
$$

$\mathrm{NCO}_{2}$ values show that $\mathrm{CSA} 20$ presents the least normalized $\mathrm{CO}_{2}$ emissions (0.0075), being those for CSAR and CSA35 equal to 0.0084 and 0.0088 , respectively.

\section{Conclusions}

This paper evaluated the possibility of using water potabilization sludges (WPSs) as an alternative supplementary cementitious material in calcium sulfoaluminate (CSA)-blended cements. WPSs were thermally treated (TT) at $700{ }^{\circ} \mathrm{C}$ with the aim of dehydroxylating the silico-aluminate crystalline phases to an amorphous state; TTWPSs are very interesting as their use as a secondary cementitious component can permit the saving of raw materials and the avoidance of their landfilling; moreover, its use allows for the dilution of the CSA cement and thus determines the following environmental benefits: (i) decreased $\mathrm{CO}_{2}$ emissions; (ii) energy saving per unit mass of cement; (iii) withdrawal reduction in natural resources.

From DT-TG and QXRD analyses, it was established that TTWPSs did not affect the formation of the main hydration products of CSA cement, namely, ettringite, aluminum hydroxide and calcium silicate hydrates; the latter derived from both the hydration of dicalcium silicate present in the cement and the pozzolanic reaction between $\mathrm{SiO}_{2}$ (belonging to TTWPSs) and $\mathrm{Ca}(\mathrm{OH})_{2}$ (formed as secondary phase from $\mathrm{C}_{2} \mathrm{~S}$ hydration).

Binders containing $20 \%$ by mass of TTWPSs (CSA20) displayed the same compressive strength as the neat CSA cement; furthermore, when 35\% by mass of TTWPSs was added, only a slightly negative effect $(-18 \%)$ on the technical behavior of CSA cement was detected 
at the longest curing period. Moreover, the utilization of TTWPSs, up to $35 \%$ by mass, did not significantly influence both the porosimetric features and the dimensional stability of blended cement pastes.

Finally, the experimental findings, coupled with the calculations of both kiln thermal requirement and $\mathrm{CO}_{2}$ emissions, open up the possibilities for producing binders (e.g., CSA20) characterized by reliable technical properties and a reduced impact on the environment.

Author Contributions: A.T.: conceptualization; methodology; formal analysis; investigation; data curation; writing—original draft preparation; writing—review and editing. N.I.: formal analysis; investigation. M.M.: conceptualization; methodology; formal analysis; investigation; data curation; writing—original draft preparation; writing-review and editing. All authors have read and agreed to the published version of the manuscript.

Funding: This research received no external funding.

Institutional Review Board Statement: Not applicable.

Informed Consent Statement: Not applicable.

Data Availability Statement: Not applicable.

Conflicts of Interest: The authors declare no conflict of interest.

\section{References}

1. Telesca, A.; Matschei, T.; Marroccoli, M. Study of eco-friendly belite-calcium sulfoaluminate cements obtained from special wastes. Appl. Sci. 2020, 10, 8650. [CrossRef]

2. IEA. 2020. Available online: https://www.iea.org/reports/global-energy-review-2020/global-energy-and-co2-emissions-in-20 20 (accessed on 27 January 2021).

3. Barcelo, L.; Kline, J.; Walenta, G.; Gartner, E. Cement and carbon emissions. Mater. Struct. 2014, 47, 1055-1065. [CrossRef]

4. Schneider, M. The cement industry on the way to a low-carbon future. Cem. Concr. Res. 2019, 124, 105792. [CrossRef]

5. Shi, C.; Qu, B.; Provis, J.L. Recent progress in low-carbon binders. Cem. Concr. Res. 2019, 122, 227-250. [CrossRef]

6. Gartner, E.; Sui, T. Alternative cement clinkers. Cem. Concr. Res. 2018, 114, 27-39. [CrossRef]

7. Tregambi, C.; Solimene, R.; Montagnaro, F.; Salatino, P.; Marroccoli, M.; Ibris, N.; Telesca, A. Solar-driven production of lime for ordinary Portland cement formulation. Sol. Energy 2018, 173, 759-768. [CrossRef]

8. Gartner, E.; Hirao, H. A review of alternative approaches to the reduction of $\mathrm{CO}_{2}$ emissions associated with the manufacture of the binder phase in concrete. Cem. Concr. Res. 2015, 78, 126-142. [CrossRef]

9. Juenger, M.C.G.; Winnefeld, F.; Provis, J.L.; Ideker, J.H. Advances in alternative cementitious binders. Cem. Concr. Res. 2011, 41, 1232-1243. [CrossRef]

10. Telesca, A.; Marroccoli, M.; Tomasulo, M.; Valenti, G.L.; Dieter, H.; Montagnaro, F. Calcium looping spent sorbent as a limestone replacement in the manufacture of Portland and calcium sulfoaluminate cements. Environ. Sci. Technol. 2015, 49, 6865-6871. [CrossRef] [PubMed]

11. Marroccoli, M.; Montagnaro, F.; Pace, M.L.; Telesca, A.; Valenti, G.L. Utilization of coal combustion ashes for the synthesis of ordinary and special cements. Combust. Sci. Technol. 2010, 182, 588-599. [CrossRef]

12. Cardinale, T.; D'Amato, M.; Sulla, R.; Cardinale, N. Mechanical and Physical Characterization of Papercrete as New Eco-Friendly Construction Material. Appl. Sci. 2021, 11, 1011. [CrossRef]

13. Diaz-Loya, I.; Juenger, M.; Seraj, S.; Minkara, R. Extending supplementary cementitious material resources: Reclaimed and remediated fly ash and natural pozzolans. Cem. Concr. Compos. 2019, 101, 44-51. [CrossRef]

14. Juenger, M.C.G.; Snellings, R.; Bernal, S.A. Supplementary cementitious materials: New sources, characterization, and performance insights. Cem. Concr. Res. 2019, 122, 257-273. [CrossRef]

15. Snellings, R. Assessing, understanding and unlocking supplementary cementitious materials. RILEM Tech. Lett. 2016, 1, 50-55. [CrossRef]

16. Juenger, M.C.G.; Siddique, R. Recent advances in understanding the role of supplementary cementitious materials in concrete. Cem. Concr. Res. 2015, 78, 71-80. [CrossRef]

17. De Weerdt, K.; Ben Haha, M.; Le Saout, G.; Kjellsen, K.O.; Justnes, H.; Lothenbach, B. Hydration mechanisms of ternary Portland cements containing limestone powder and fly ash. Cem. Concr. Res. 2011, 41, 279-291. [CrossRef]

18. Mobili, A.; Telesca, A.; Marroccoli, M.; Tittarelli, F. Calcium sulfoaluminate and alkali-activated fly ash cements as alternative to Portland cement: Study on chemical, physical-mechanical, and durability properties of mortars with the same strength class. Constr. Build. Mater. 2020, 246, 118436. [CrossRef]

19. Dung, N.T.; Unluer, C. Development of $\mathrm{MgO}$ concrete with enhanced hydration and carbonation mechanisms. Cem. Concr. Res. 2018, 103, 160-169. [CrossRef] 
20. Gomez, C.M.; de Oliveira, A.D.S. Chemical phases and microstructural analysis of pastes based on magnesia cement. Constr. Build. Mater. 2018, 188, 615-620. [CrossRef]

21. Luukkonen, T.; Abdollahnejad, Z.; Yliniemi, J.; Kinnunen, P.; Illikainen, M. One-part alkali-activated materials: A review. Cem. Concr. Res. 2018, 103, 21-34. [CrossRef]

22. Mobili, A.; Belli, A.; Giosué, C.; Telesca, A.; Marroccoli, M.; Tittarelli, F. Calcium sulfoaluminate, geopolimeric, and cementitious mortars for structural applications. Environments 2017, 4, 64. [CrossRef]

23. Myers, R.J.; Lothenbach, B.; Bernal, S.A.; Provis, J.L. Thermodynamic modelling of alkali-activated slag cements. J. Appl. Geochem. 2015, 61, 233-247. [CrossRef]

24. Walling, S.A.; Provis, J.L. Magnesia-based cements: A journey of 150 years, and cements for the future? Chem. Rev. 2016, 116, 4170-4204. [CrossRef]

25. Provis, J.L.; van Deventer, J.S.J. Alkali-Activated Materials: State-of-the-Art Report; RILEM TC 224-AAM, 2014; Provis, J., van Deventer, J., Eds.; Springer: Dordrecht, The Netherlands, 2014. [CrossRef]

26. Marroccoli, M.; Montagnaro, F.; Telesca, A.; Valenti, G.L. Environmental implications of the manufacture of calcium sulfoaluminate-based cements. In Proceedings of the 2nd International Conference on Sustainable Construction Materials and Technologies, Ancona, Italy, 28-30 June 2010; Zachar, J., Claisse, P., Naik, T.R., Ganjiam, E., Eds.; UWM Center for By-Products Utilization: Milwaukee, WI, USA, 2010.

27. Marroccoli, M.; Nobili, M.; Telesca, A.; Valenti, G.L. Early hydration of calcium sulfoaluminate-based cements for structural applications. In Proceedings of the International Conference on Sustainable Construction Materials and Technology, Coventry, UK, 11-13 June 2007; pp. 389-395.

28. Wang, L.; Zhan, S.; Tang, X.; Xu, Q.; Qian, K. Pore Solution Chemistry of Calcium Sulfoaluminate Cement and Its Effects on Steel Passivation. Appl. Sci. 2019, 9, 1092. [CrossRef]

29. Telesca, A.; Marroccoli, M.; Pace, M.L.; Tomasulo, M.; Valenti, G.L.; Monteiro, P.J.M. A hydration study of various calcium sulfoaluminate cements. Cem. Concr. Comp. 2014, 53, 224-232. [CrossRef]

30. Chen, I.A.; Hargis, C.W.; Juenger, M.C.G. Understanding expansion in calcium sulfoaluminate-belite cements. Cem. Concr. Res. 2012, 42, 51-60. [CrossRef]

31. Winnefeld, F.; Lothenbach, B. Hydration of calcium sulfoaluminate cements-Experimental findings and thermodynamic modelling. Cem. Concr. Res. 2010, 40, 1239-1247. [CrossRef]

32. Glasser, F.P.; Zhang, L. High-performance cement matrices based on calcium sulphoaluminate-belite compositions. Cem. Concr. Res. 2001, 31, 1881-1886. [CrossRef]

33. Telesca, A.; Marroccoli, M.; Winnefeld, F. Synthesis and characterization of calcium sulfoaluminate cements produced by different chemical gypsums. Adv. Cem. Res. 2019, 31, 113-123. [CrossRef]

34. Xu, L.; Wu, K.; Li, N.; Zhou, X.; Wang, P. Utilization of flue gas desulfurization gypsum for producing calcium sulfoaluminate cement. J. Clean. Prod. 2017, 161, 803-811. [CrossRef]

35. Telesca, A.; Marroccoli, M.; Tomasulo, M.; Valenti, G.L.; Dieter, H.; Montagnaro, F. Low-CO $\mathrm{CO}_{2}$ Cements from Fluidized Bed Process Wastes and Other Industrial By-Products. Comb. Sci. Tech. 2016, 188, 492-503. [CrossRef]

36. Shen, Y.; Qian, J.; Chai, J.; Fan, Y. Calcium sulphoaluminate cements made with phosphogypsum: Production issues and material properties. Cem. Concr. Res. 2014, 48, 67-74. [CrossRef]

37. Wu, K.; Shi, H.; Guo, X. Utilization of municipal solid waste incineration fly ash for sulfoaluminate cement clinker production. Waste Manag. 2011, 31, 2001-2008. [CrossRef]

38. Marroccoli, M.; Pace, M.L.; Telesca, A.; Valenti, G.L. Synthesis of calcium sulfoaluminate cements from $\mathrm{Al}_{2} \mathrm{O}_{3}$-rich by-products from aluminium manufacture. In Proceedings of the 2nd International Conference on Sustainable Construction Materials and Technologies, Ancona, Italy, 28-30 June 2010; Zachar, J., Claisse, P., Naik, T.R., Ganjiam, E., Eds.; UWM Center for By-Products Utilization: Milwaukee, WI, USA, 2010.

39. Marroccoli, M.; Montagnaro, F.; Pace, M.L.; Telesca, A.; Valenti, G.L. Use of fluidized bed combustion ash and other industrial wastes as raw materials for the manufacture of calcium sulphoaluminate cements. In Proceedings of the 20th International Conference on Fluidized Bed Combustion, Xian, China, 18-21 May 2009; Yue, G., Zhang, H., Zhao, C., Luo, Z., Eds.; Springer: Berlin/Heidelberg, Germany, 2009; pp. 389-395.

40. Adolfsson, D.; Menad, N.; Viggh, E.; Bjorkman, B. Steelmaking slags as raw material for sulphoaluminate belite cement. Adv. Cem. Res. 2007, 19, 147-156. [CrossRef]

41. Gao, D.; Zhang, Z.; Meng, Y.; Tang, J.; Yang, L. Effect of Flue Gas Desulfurization Gypsum on the Properties of Calcium Sulfoaluminate Cement Blended with Ground Granulated Blast Furnace Slag. Materials 2021, 14, 382. [CrossRef]

42. Kim, T.; Ki_Young, Y.S.; Kang, C.; Lee, T.-K. Development of Eco-Friendly Cement Using a Calcium Sulfoaluminate Expansive Agent Blended with Slag and Silica Fume. Appl. Sci. 2021, 11, 394. [CrossRef]

43. Yoon, H.N.; Seo, J.; Kim, S.; Lee, H.K.; Park, S. Hydration of calcium sulfoaluminate cement blended with blast-furnace slag. Const. Build. Mat. 2021, 268, 121214. [CrossRef]

44. Niu, M.; Zhang, J.; Li, G.; Song, Z.; Wang, X. Mechanical properties of polyvinyl alcohol fiber reinforced sulfoaluminate cement mortar containing high-volume of fly ash. J. Build. Eng. 2021, 35, 101988. [CrossRef] 
45. Coppola, L.; Coffetti, D.; Crotti, E.; Dell'Aversano, R.; Gazzaniga, G.; Pastore, T. Influence of Lithium Carbonate and Sodium Carbonate on Physical and Elastic Properties and on Carbonation Resistance of Calcium Sulphoaluminate-Based Mortars. Appl. Sci. 2020, 10, 176. [CrossRef]

46. Ding, H.; Zhang, S. Quicklime and Calcium Sulfoaluminate Cement Used as Mineral Accelerators to Improve the Properties of Cemented Paste Backfill with a High Volume of Fly Ash. Materials 2020, 13, 4018. [CrossRef]

47. Ke, G.; Zhang, J.; Xie, S.; Pei, T. Rheological behavior of calcium sulfoaluminate cement paste with supplementary cementitious materials. Constr. Build. Mater. 2020, 243, 118234. [CrossRef]

48. Liao, Y.; Jiang, G.; Wang, K.; Qunaynah, S.A.; Yuan, W. Effect of steel slag on the hydration and strength development of calcium sulfoaluminate cement. Constr. Build. Mater. 2020, 265, 12030. [CrossRef]

49. Bertola, F.; Gastaldi, D.; Canonico, F.; Paul, G. CSA and slag: Towards CSA composite binders. Adv. Cem. Res. 2019, 31, 147-158. [CrossRef]

50. Bullerjahn, F.; Zajac, M.; Skocek, J.; Ben Haha, M. The role of boron during the early hydration of belite ye'elimite ferrite cements. Constr. Build. Mat. 2019, 215, 252-263. [CrossRef]

51. Gao, D.; Meng, Y.; Yang, L.; Tang, J.; Lv, M. Effect of ground granulated blast furnace slag on the properties of calcium sulfoaluminate cement. Constr. Build. Mater. 2019, 227, 116665. [CrossRef]

52. Jun, Y.; Hong Kim, J.; Kim, T. Hydration of Calcium Sulfoaluminate-Based Binder Incorporating Red Mud and Silica Fume. Appl. Sci. 2019, 9, 2270. [CrossRef]

53. Martin, L.H.J.; Winnefeld, F.; Tschopp, E.; Müller, C.J.; Lothenbach, B. Influence of fly ash on the hydration of calcium sulfoaluminate cement. Cem. Concr. Res. 2017, 95, 152-163. [CrossRef]

54. Martin, L.H.J.; Winnefeld, F.; Müller, C.J.; Lothenbach, B. Contribution of limestone to the hydration of calcium sulfoaluminate cement. Cem. Con. Comp. 2015, 62, 204-211. [CrossRef]

55. Hargis, G.W.; Telesca, A.; Monteiro, P.J.M. Calcium sulfoaluminate (ye'elimite) hydration in the presence of gypsum, calcite and vaterite. Cem. Concr. Res. 2014, 65, 15-20. [CrossRef]

56. Ioannou, S.; Reig, L.; Paine, K.; Quillin, K. Properties of a ternary calcium sulfoaluminate-calcium sulfate-fly ash cement. Cem. Concr. Res. 2014, 56, 75-83. [CrossRef]

57. García-Maté, M.; De la Torre, A.G.; León-Reina, L.; Aranda, M.A.; Santacruz, I. Hydration studies of calcium sulfoaluminate cements blended with fly ash. Cem. Concr. Compos. 2013, 54, 12-20. [CrossRef]

58. Martin, L.H.J.; Winnefeld, F.; Müller, C.J.; Lothenbach, B. Influence of limestone on the hydration of calcium sulfoaluminate cement. In Proceedings of the First International Conference on Sulphoaluminate Cement: Materials and Engineering Technology, Wuhan, China, 23-24 October 2013; Xu, Y., Zhang, Q., Eds.; WUT Press: Wuhan, China, 2013; pp. 229-245.

59. Chen, I.A.; Juenger, M.C.J. Incorporation of coal combustion residuals into calcium sulfoaluminate- belite cement clinkers. Cem. Concr. Res. 2012, 34, 893-902. [CrossRef]

60. Pelletier-Chaignat, L.; Winnefeld, F.; Lothenbach, B.; Müller, C.J. Beneficial use of limestone filler with calcium sulfoaluminate cement. Constr. Build. Mater. 2012, 26, 619-627. [CrossRef]

61. Ferone, C.; Capasso, I.; Bonati, A.; Roviello, G.; Montagnaro, F.; Santoro, L.; Turco, R.; Cioffi, R. Sustainable management of water potabilization sludge by means of geopolymers production. J. Clean. Prod. 2019, 229, 1-9. [CrossRef]

62. Ahmad, T.; Ahmad, K.; Alam, M. Sustainable management of water treatment sludge through 3'R' concept. J. Clean. Prod. 2016, 124, 1-13. [CrossRef]

63. Mohammed, S. Processing effect and reactivity assessment of artificial pozzolans obtained from clays and clay wastes: A review. Constr. Build. Mater. 2017, 140, 10-19. [CrossRef]

64. Telesca, A. (University of Basilicata, Potenza, Italy); Marroccoli, M. (University of Basilicata, Potenza, Italy). Personal communication. 2019.

65. Taylor, H.F.W. Cement Chemistry, 2nd ed.; Academic Press: London, UK, 1997; p. 480. [CrossRef]

66. Naqi, A.; Jang, J.G. Recent Progress in Green Cement Technology Utilizing Low-Carbon Emission Fuels and Raw Materials: A Review. Sustainability 2019, 11, 537. [CrossRef]

67. Coppola, L.; Coffetti, D.; Crotti, E. An holistic approach to a sustainable future in concrete construction. IOP Conf. Ser. Mater. Sci. Eng. 2018, 442, 012024. [CrossRef]

68. Madlool, N.A.; Saidur, R.; Rahim, N.A.; Kamalisarvestani, M. An overview of energy savings measures for cement industries, Renew. Sustain. Energ. Rev. 2013, 19, 18-29. [CrossRef]

69. Van den Heede, P.; De Belie, N. Environmental impact and life cycle assessment (LCA) of traditional and 'green' concretes: Literature review and theoretical calculations. Cem. Concr. Res. 2012, 34, 431-442. [CrossRef]

70. Imbabi, M.S.; Carrigan, C.; McKenna, S. Trends and developments in green cement and concrete technology. Int. J. Sustain. Built Env. 2012, 1, 194-216. [CrossRef]

71. Damtoft, J.S.; Lukasik, J.; Herfort, D.; Sorrentino, D.; Gartner, E.M. Sustainable development and climate change initiatives. Cem. Concr. Res. 2008, 38, 115-127. [CrossRef]

72. Worrell, E.; Martin, N.; Price, L. Potentials for energy efficiency improvement in the US cement industry. Energy 2000, 25, 1189-1214. [CrossRef]

73. Chatterjee, A.; Sui, T. Alternative fuels_Effects on clinker process and properties. Cem. Concr. Res. 2019, 103, 105777. [CrossRef] 
74. Kajaste, R.; Hurme, M. Cement industry greenhouse gas emissions e management options and abatement cost. J. Clean. Prod. 2016, 112, 4041-4052. [CrossRef]

75. Coppola, L.; Coffetti, D.; Crotti, E.; Gazzaniga, G.; Pastore, T. An Empathetic Added Sustainability Index (EASI) for cementitious based construction materials. J. Clean. Prod. 2019, 220, 475-482. [CrossRef]

76. Ludwig, H.M.; Zhang, W. Research review of cement clinker chemistry. Cem. Concr. Res. 2015, 78, 24-37. [CrossRef]

77. Schneider, M. Process technology for efficient and sustainable cement production. Cem. Concr. Res. 2015, 78, 14-23. [CrossRef]

78. Technology Roadmap: Low-Carbon Transition in the Cement Industry; International Energy Agency. 2018. Available online: https: / /www.wbcsd.org/Sector-Projects/Cement-Sustainability-Initiative/Resources/Technology-Roadmap-Low-CarbonTransition-in-the-Cement-Industry (accessed on 27 January 2021).

79. Jaskulski, R.; Jóźwiak-Niedźwiedzka, D.; Yakymechko, Y. Calcined Clay as Supplementary Cementitious Material. Materials 2020, 13, 4734. [CrossRef]

80. Dãaz, Y.C.; Berriel, S.S.; Heierli, U.; Favier, A.R.; Machado, I.R.S.; Scrivener, K.L.; Hernãjndez, J.F.M.; Habert, G. Limestone calcined clay cement as a low-carbon solution to meet expanding cement demand in emerging economies. Dev. Eng. 2017, 2, 82-91. [CrossRef] 